\title{
THE INFLUENCE OF GEOGRAPHIC LOCATION AND ENZYME-ASSISTED EXTRACTION ON ESSENTIAL OILS COMPOSITION OF THYMUS SERPYLLUM GROWING WILD IN TRANSYLVANIA
}

\author{
IOANA GOJA ${ }^{a}$, ADELINA ULICl ${ }^{a}$, MONICA CULEA ${ }^{b}$, \\ VASILE MUNTEANU' ${ }^{\mathrm{c}}$, PAULA PODEA ${ }^{\mathrm{a}}$
}

\begin{abstract}
A comparative study concerning the influence of geographic location and also the influence of enzyme-assisted extraction on the essential oils isolated from Transylvanian wild Thymus serpyllum was achieved. The collected Thymus serpyllum plants, from three different regions from Transilvania, were hydrodistilled to yield essential oils. The influence of enzymatic assisted extraction on the essential oils isolated from Thymus serpyllum was evaluated. All analyzed plants proved to belong to carvacrol chemotype class. The major constituents of wild Thymus serpyllum from these three regions were carvacrol (26.58\%-47.62\%), p-cymene (8.61\%-18.97\%), methylcarvacrol (8.81\%-13.35\%), thymol (1.6\%-11.07\%), gamma-terpinene $(2.09 \%-7.55 \%)$, beta-bysabolene $(3.42 \%-5.18 \%)$, caryophyllene (3.17\%-4.83\%). Using the enzymatic treatment, the percentage in composition of some components was modified and proved to have an improvement on antioxidant and antimicrobial properties. All studied essential oils exhibited considerable antioxidant and antimicrobial activity.
\end{abstract}

Keywords: Thymus serpyllum essential oils, enzyme assisted extraction, antioxidant activity, antimicrobial activity, GC/MS

a Babes-Bolyai University, Faculty of Chemistry and Chemical Engineering, Kogalniceanu str. No. 1, RO-400084 Cluj-Napoca, Romania

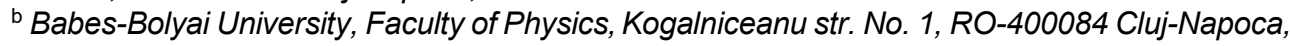
Romania

${ }^{c}$ Babes-Bolyai University, Faculty of Biology and Geology, Kogalniceanu str. No. 1, RO-400084 Cluj-Napoca, Romania

*Corresponding author: mpaula@chem.ubbcluj.ro 


\section{INTRODUCTION}

Thymus serpyllum $\mathrm{L}$, also known as wild thyme, belongs to the Lamiaceae plant family. Thymus serpyllum is growing spontaneous in extended regions of northern and central Europe and at high altitude in Mediterranean areas ${ }^{1}$.

Based on several studies Thymus serpyllum essential oil are an excellent source of bioactive compounds with powerful antioxidant, strong antibacterial and antifungal activity, anti-inflammatory, antitumor, and cytotoxic properties ${ }^{1,2,3}$.

A highly variation in Thymus serpyllum essential oil compounds proportion was observed due to the origin, environmental condition oil also with plant stage of development and metabolism ${ }^{4}$. The essential oils isolated from Thymus genus plants, are characterized by a chemical polymorphism. Depending on source and geographical location several chemotypes (geraniol, germacrene D, citral, linalool, (E) caryophyllene, $\alpha$-terpinyl acetate, carvacrol, and thymol) has been considered ${ }^{1}$. Growing spontaneous, Thymus serpyllum could also been characterized by a variety of chemotypes, even within on growing area ${ }^{5}$.

Due to great variability in Thymus serpyllum essential oil composition, the evaluation of Thymus serpyllum grown wild in different regions is of high interest. Climatic conditions and the applied extraction technique, can influence both the qualitative composition and contents of the individual components of the isolated essential oils and consequently the bioactive properties like antioxidant and antimicrobial activity. Enzyme-assisted extraction technique is emerging as an alternative and eco-friendly approach to extract volatile oils. The biotechnological application of enzymes is not currently exploited to its maximum potential. Hydrolytic enzymes can interact with cell walls, break down their structural integrity and facilitate the release of intracellular contents from plant materials ${ }^{6}$. In this way, enzymes will ease the extraction and higher yields in essential oils will be obtained. Also, using this enzymatic treatment, the flavours profile can be easily modified, in sense that the percentage in composition of some components can be enhanced and also as a result of these different bioactive properties can appear. Enzymatic treatment in essential oil obtained from some spices as fenugreek, garlic, cumin, celery, pepper, mustard, chilli and citrus peel has been reported ${ }^{7,8,9,10,11,12,13}$. Also results about the enzymatic influence on Thymus capitatus and Rosmarinus officinalis leaves were reported ${ }^{14}$.

In order to establish the impact of geographic location on the composition of the volatile oils, we propose a comparison study on isolated essential oils from Thymus serpyllum plants, collected from three different 
geographic areas of Transylvania, Romania. Our purpose is to investigate the isolated essential oils chemical components and to compare them in terms of antioxidant and antimicrobial activities. Also, the influence of an enzymatic the effects of enzymatic pre-treatment on the yields, chemical composition and biological properties of Thymus serpyllum essential oil will be evaluated.

\section{RESULTS AND DISCUSSION}

The goal of this work was to obtain a comparative study concerning the influence of the growth regions and also the influence of enzymatic assistant extraction on the essential oils isolated from Thymus serpyllum. The collected Thymus serpyllum plants were from three different regions from Transilvania. Chemical composition, the antioxidant and antimicrobial activities of isolated essential oils were determined and compared. The influence of enzymatic assistant extraction on the essential oils isolated from Thymus serpyllum was investigated. The essential oil form plants collected from Nasaud area was extracted using classic Clevenger method and comparative the plant was treated with an enzymatic preparate with a cellulosic and pectolytic activity followed by Clevenger hydrodistillation.

The Thymus serpyllum volatile oils obtained were light-yellow in color with herbaceous odor. Identification of chemical components in isolated essential oils by GC/MS was investigated.

\section{The essential oils yields and the chemical composition of the essential oil analyzed by GC-MS}

The yields of the obtained essential oils are provided in Table 1. Comparing the obtained essential oils from selected Thymus serpyllum plants, the highest yield was obtained for essential oil obtained from Nasaud area $(0.50 \pm 0.1(\% \mathrm{v} / \mathrm{w}))$, followed by Tamasesti area $(0.41 \pm 0.1(\% \mathrm{v} / \mathrm{w}))$. The lowest essential oils yield was obtained in case of Mociu area $(0.34 \pm 0.1(\% \mathrm{v} / \mathrm{w}))$. The obtained essential oil yields are comparable, not such a big difference was observed. In case of the plant enzymatic treatment a yield improvement was observed with $12 \%(0.56 \pm 0.1(\% \mathrm{v} / \mathrm{w}))$. The effect of enzymes treatment on the essential oil yield was not so high, but differences in compositon were observed.

There are some reports on chemical composition and yields of the essential oils from Thymus serpyllum and from these studies we can conclude that chemical composition and yields are consider to be highly affected of 
factors like climatic conditions, geographic growth region, stage of plant maturity and even the altitude of the growth region ${ }^{1,4,5}$. Our results were similar with literature reported yields. The reported Thymus serpyllum essential oils yields, originated from different countries is between $0.07 \%$ to $0.6 \%{ }^{5}$ and even higher 0.1 to $1 \%{ }^{15}$. For Thymus serpyllum grown in Northen Kazakhstan, the essential oils yields were between $0.4-1.4 \%^{16}$.

Table 1. Essential oils yields.

\begin{tabular}{|c|c|}
\hline Yield(\%v/w) & Thymus serpyllum \\
\hline $0.38 \pm 0.05$ & Mociu area \\
\hline $0.41 \pm 0.05$ & Tamasesti area \\
\hline $0.50 \pm 0.05$ & Nasaud area \\
\hline $0.56 \pm 0.05$ & Nasaud area enzymatically treated \\
\hline
\end{tabular}

The main components of the essential oils obtained from Thymus serpyllum plants are presented in Table 2. Identification of the constituents was based on comparison with mass fragmentation pattern and spectral comparison using NIST and Wiley mass spectra libraries of standards.

Totally 70 components were identified in the analysed plants. The composition of the studied essential oils showed that the plants are related, but differences appear in compounds relative concentration. The major constituents of Thymus serpyllum growing in these three regions from Transylvania were carvacrol $(26.58 \%$ - $47.62 \%)$, p-cymene $(8.61 \%-18.97 \%)$, methylcarvacrol (8.81\%-13.35\%), thymol (1.6\%-11.07\%), gamma-terpinene $(2.09 \%-7.55 \%)$, beta-bysabolene (3.42\%-5.18\%), caryophyllene (3.17\%-4.83\%). In all three analysed essential oils, carvacrol was the majority compound.

According to Thymus serpyllum research studies, there is high variability in chemical composition of studied essential oils. Thymus serpyllum essential oil has a variety of chemotypes. Carvacrol is considered the main component, conformable to PDR from Herbal Medicine ${ }^{1}$, but a number of studies present thymol as the major constituent in Thymus serpyllum essential oils ${ }^{2,17}$. Thymol is the isomer of carvacrol, so differences between their ratio can exist. European Pharmacopeia agreed that a total content of carvacrol and tymol should be around $40 \%$ or more ${ }^{1}$. Even that carvacrol and thymol are considered the principal components, some studies show other main constituents, carvacrol and thymol being just minority constituents $1,5,18,19,20$. In some essential oil obtained from Thymus serpyllum growing wild in Lithuania, carvacrol and thymol weren't identified, the major components were 1,8-cineole (16.3-19.0\%), myrcene (9.7-10.7 \%), 3-caryophyllene (9.6$11.3 \%)$, germacrene $\mathrm{D}(5.9-8.0 \%)^{21}$. The significant variety in composition is 
THE INFLUENCE OF GEOGRAPHIC LOCATION AND ENZYME-ASSISTED EXTRACTION ON ESSENTIAL OILS COMPOSITION OF THYMUS SERPYLLUM GROWING WILD IN TRANSYLVANIA

connected with plant stage of development and metabolism and also with climatic conditions and geographic position of the growth region. An example was given by content of Thymus serpyllum essential oil growing wild in Altai Mountains, in which compositional differences appear depending on the altitude $^{22}$. Also Thymus serpyllum grown in Kumaon region of Western Himalaya was investigated, and seasonal variation in essential oil composition was found ${ }^{4}$.

Table 2. Chemical composition of the obtained essential oils analysed by GC-MS

\begin{tabular}{|c|c|c|c|c|c|c|}
\hline & & & \multicolumn{4}{|c|}{ Thymus serpyllum \% } \\
\hline Component & $\mathbf{M}$ & RT & Mociu & Tamasesti & Nasaud & $\begin{array}{c}\text { Nasaud } \\
\text { enzymatic }\end{array}$ \\
\hline thujene & 136 & 7.58 & & & 0.47 & \\
\hline alpha -pinene & 136 & 7.76 & 0.59 & 0.29 & 1.13 & \\
\hline trans- ocimene & 136 & 7.83 & - & 0.39 & & \\
\hline carene & 136 & 8.07 & - & 0.19 & 0.15 & \\
\hline camphene & 136 & 8.37 & 0.31 & - & 0.79 & \\
\hline beta-myrcene & 136 & 9.23 & 1.17 & 0.81 & & \\
\hline beta-pinene & 136 & 9.52 & 0.21 & 0.58 & 0.71 & \\
\hline 1-octen-3-ol & 130 & 9.98 & 3.3 & 1.7 & 1.26 & 1. \\
\hline delta-carene & 128 & 10.18 & - & - & 0.19 & \\
\hline cis ocimene & 136 & 10.48 & - & - & & $<0.1$ \\
\hline alpha- terpinene & 136 & 10.62 & 1.13 & - & 0.91 & \\
\hline p-cymene & 134 & 10.99 & 10.66 & 8.61 & 18.97 & 2.37 \\
\hline limonene & 136 & 11.04 & - & 0.31 & & \\
\hline eucaliptol & 136 & 11.11 & - & - & - & 0 \\
\hline sabinene & 136 & 11.61 & - & $<0.1$ & $<0.1$ & \\
\hline gamma-terpinene & 136 & 12.07 & 7.55 & 2.09 & 3.95 & 0.52 \\
\hline beta ocimene & 136 & 12.97 & - & - & - & $<0.1$ \\
\hline terpinolene & 136 & 13.03 & & 0.09 & 0.14 & \\
\hline linalool & 136 & 13.59 & 1.64 & 2.6 & 0.78 & \\
\hline terpineol & 154 & 13.82 & - & $<0.1$ & 0.14 & $<0$ \\
\hline octyl-acetate & 172 & 14.16 & - & 0.32 & - & \\
\hline verbenol & 152 & 14.3 & - & 0.1 & - & $<0.1$ \\
\hline tujanol & 152 & 14.58 & $<0.1$ & $<0.1$ & 0.09 & 0.14 \\
\hline camphor & 152 & 15.49 & 0.12 & 0.09 & 0.14 & 0.25 \\
\hline citronellol & 156 & 15.62 & & - & - & 0.14 \\
\hline izomentona & 154 & 15.75 & - & 0.17 & $<0.1$ & \\
\hline Borneol & 154 & 16.36 & 3.1 & 2.27 & 1.8 & 0.8 \\
\hline 4-terpineol & 154 & 16.6 & 1.49 & 1.39 & 0.91 & 3.18 \\
\hline thujone & 152 & 16.78 & & 0.17 & 0.48 & \\
\hline
\end{tabular}




\begin{tabular}{|c|c|c|c|c|c|c|}
\hline \multicolumn{7}{|c|}{ Table 2 (continued) } \\
\hline Component & $\mathbf{M}$ & RT & Mociu & Tamasesti & Nasaud & $\begin{array}{c}\text { Nasaud } \\
\text { enzymatic }\end{array}$ \\
\hline cuminol & 150 & 16.94 & - & & 0.25 & $<0.1$ \\
\hline beta-fenchol & 150 & 17.32 & 0.5 & 0.1 & 0.31 & 0.64 \\
\hline cis-carveol & 152 & 17.35 & & $<0.1$ & - & \\
\hline p-cymen-8-ol & 150 & 17.5 & 0.6 & - & - & 0.29 \\
\hline carvomenthol & 156 & 17.96 & 0.15 & $<0.1$ & - & - \\
\hline trans-carveol & 152 & 18.15 & & 0.1 & - & \\
\hline thymol methyl & 164 & 1823 & 415 & 378 & 3.34 & 374 \\
\hline methylcarvacrol & 164 & 18.62 & 13.35 & 8.81 & 9.17 & 8.21 \\
\hline thymoquinone & 164 & 19.18 & 0.46 & $<0.1$ & - & 0.74 \\
\hline geraniol & 154 & 19.24 & & 0.09 & 1.58 & 1.95 \\
\hline piperitona & 152 & 19.83 & 0.17 & 2.62 & 0.94 & \\
\hline izopiperitona & 152 & 19.9 & & 0,28 & - & \\
\hline cis-geraniol & 154 & 20.08 & - & - & - & $<0.1$ \\
\hline dihydroedulan & 194 & 20.27 & - & 0.1 & - & - \\
\hline thymol & 150 & 20.67 & 4.84 & 1.6 & 11.07 & 24.01 \\
\hline carvacrol & 150 & 21.11 & 31.32 & 47.62 & 26.58 & 28.81 \\
\hline isoeugenol & 164 & 21.83 & - & - & - & 0.11 \\
\hline terpinyl acetate & 196 & 22.24 & $<0.1$ & 0.11 & 0.39 & 0.52 \\
\hline eugenol & 164 & 22.65 & & - & - & 0.6 \\
\hline carvacryl acetat & 192 & 22.87 & - & $<0.1$ & $<0.1$ & \\
\hline copaene & 204 & 23.08 & - & 1.3 & 0.09 & 0.13 \\
\hline geranyl acetate & 198 & 23.18 & - & - & 0.15 & 0.27 \\
\hline beta-bourbonene & 204 & 23.36 & 0.1 & 1.18 & 0.22 & 0.37 \\
\hline Iongifolene & 204 & 24.04 & & - & - & 0.15 \\
\hline caryophyllene & 204 & 24.6 & 4.83 & 3.17 & 4.49 & 4.1 \\
\hline germacrene & 204 & 24.87 & 0.09 & 0.12 & 0.15 & 0.23 \\
\hline aromadendrene & 204 & 25.14 & & 0.09 & $<0.1$ & 0.12 \\
\hline farnesene & 204 & 25.44 & - & - & 0.09 & 0.19 \\
\hline humulene & 204 & 25.71 & $<0.1$ & $<0.1$ & 0.24 & 0.25 \\
\hline muurolene & 204 & 26.29 & $<0.1$ & $<0.1$ & 0.26 & 0.53 \\
\hline cubebene & 204 & 26.51 & 0.14 & 0.43 & 0.24 & 0.33 \\
\hline valencene & 204 & 26.8 & & - & 0.16 & 0.31 \\
\hline beta-bysabolene & 204 & 27.33 & 5.18 & 3.42 & 4.31 & 5.62 \\
\hline gamma-cadinene & 204 & 27.55 & 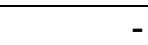 & $<0.1$ & 0.18 & 0.35 \\
\hline delta-cadinene & 204 & 27.65 & - & - & 0.28 & 0.52 \\
\hline trans-nerolidol & 222 & 29.11 & - & - & 0.55 & 3.11 \\
\hline $\begin{array}{l}\text { caryophyllene } \\
\text { oxyde }\end{array}$ & 220 & 30.28 & 2.49 & 1.98 & 1.63 & 2.21 \\
\hline
\end{tabular}


In our study the highest concentration of carvacrol was found in Tamasesti sample (47.62\%), but the concentration of thymol was little $(1.6 \%)$. Similar composition was found for Mociu sample, but a little smaller carvracrol relative concentration (31.32\%), and a higher thymol concentration (4.84\%) also a relative high methyl-carvacrol concentration (13.35\%). This kind of composition was encountered to other essential oil samples originated from Hungary ${ }^{23}$, North-East Italy ${ }^{24}$, some area in Pakistan ${ }^{25}$ and also from other Romanian region ${ }^{26}$. The Thymus serpyllum essential oil from Nasaud area, carvacrol $(26.58 \%)$, thymol $(11.07 \%)$, p-cymen $(18.97 \%)$ is similar in composition with samples originated from central Dalmatia and Bosnia and Herzegovina ${ }^{27}$, Northern Kazakhstan ${ }^{16}$ and some area in $\operatorname{Iran}^{28}$.

Even if the enzyme assisted extraction didn't have a much influence on the yield of extraction, the chemical composition suffered some modifications. In the case of carvracrol, no significant quantity increase was observed, but in case of thymol the increase was really significant from $11.07 \%$ to $24.81 \%$. An amount decreased was observed in case of p-cymen from $18.97 \%$ to $2.37 \%$. p-Cymen, it is known as a biological precursor of carvacrol and thymol ${ }^{1}$ so an enzymatic transformation could explain the increase with $100 \%$ the quantity of thymol. Actually, a decreasing in the amount of monoterpene hydrocarbons was observed from $28.76 \%$ to $3.96 \%$, while the oxygenated monoterpenes grew in quantity from $58.27 \%$ to $77.01 \%$. New compounds were identified in enzyme assisted extracted essential oil like eucalyptol $(0.4 \%)$, eugenol $(0,6 \%)$ and isoegenol $(0.1 \%)$, while other, from monoterpene hydrocarbons class, weren't identified.

The volatile compounds classes percentages are provided in Table 3 . Oxygenated monoterpenes were the predominant class in all studied oils.

Table 3. Compound classes classification in studied essential oils

\begin{tabular}{|l|c|c|c|c|}
\hline & \multicolumn{4}{|c|}{ Thymus serpyllum \% } \\
\hline \multicolumn{1}{|c|}{ Components } & Mociu & Tamasesti & Nasaud & $\begin{array}{c}\text { Nasaud } \\
\text { enzymatic }\end{array}$ \\
\hline Monoterpene hydrocarbons & 24.92 & 15.11 & 28.76 & 3.96 \\
\hline Oxygenated monoterpenes & 62.01 & 72.44 & 58.27 & 77.01 \\
\hline $\begin{array}{l}\text { Sesquiterpene } \\
\text { hydrocarbons }\end{array}$ & 10.49 & 9.88 & 10.77 & 13.2 \\
\hline Oxygenated sesquiterpenes & 2.49 & 1.98 & 2.18 & 5.32 \\
\hline
\end{tabular}




\section{Antioxidant activity}

Antioxidant activities of obtained Thymus serpyllum essential oils were investigated using DPPH scavenging method. DPPH percent scavenging activities of volatile oils were measured at different concentrations between 0.5 and $5 \mu \mathrm{l} / \mathrm{ml}$. EC50\% is a parameter used for quantification of antioxidant activity and is giving by the concentration of essential oil used for decreasing the initial DPPH concentration by $50 \%$. A lower EC50\% indicates a higher antioxidant activity. All tested essential oils presented a high antioxidant and free radical scavenging activities. The highest antioxidant activity was found for Thymus serpyllum essential oil originated in Nasaud $(E C 50 \%=2.3 \pm 0.2$ $\mu \mathrm{l} / \mathrm{ml}$ ), but comparable activity was revealed in Tamasesti essential oil $(E C 50 \%=2.8 \pm 0.1 \mu \mathrm{l} / \mathrm{ml})$. Mociu essential oil proved also a high antioxidant activity $(E C 50 \%=3.4 \pm 0.1 \mu \mathrm{l} / \mathrm{ml})$. The enzymatic extraction demonstrated to have a beneficial effect on the antioxidant activity. The essential oil obtained after enzymatic treatment exhibited a really high antioxidant activity (EC50\%= $0.6 \pm 0.1 \mu \mathrm{l} / \mathrm{ml}$ ). The high antioxidant activity could be explain due to the formation by enzymatic treatment of a high quantity of thymol and also of some quantity of eugenol with it is proved to have high antioxidant properties ${ }^{29}$.

Also in literature the Thymus serpyllum essential oil was identified like a potent antioxidant. The Thymus serpyllum essential oil originated form Crotia proved to have a higher antioxidant activity $(E C 50 \%=0.4 \mu \mathrm{g} / \mathrm{ml})^{27}$, while Thymus serpyllum essential oil originated from Greece had also a high activity $(E C 50 \%=0.96 \mu \mathrm{g} / \mathrm{ml})^{2}$. The high antioxidant activity in Thymus serpyllum essential oil, should be correlated to the phenolic compounds (thymol and carvacrol) ${ }^{30}$, but also to the large number of components which have a synergic effect ${ }^{1}$.

Table 4. Antioxidant capacity parameters

\begin{tabular}{|c|c|}
\hline Thymus serpyllum & $\mathrm{EC} 50 \%(\mu \mathrm{L} / \mathrm{mL})$ \\
\hline Mociu area & $3.4 \pm 0.1$ \\
\hline Tamasesti area & $2.8 \pm 0.1$ \\
\hline Nasaud area & $2.3 \pm 0.2$ \\
\hline $\begin{array}{c}\text { Nasaud area enzymatically } \\
\text { treated }\end{array}$ & $0.6 \pm 0.1$ \\
\hline
\end{tabular}

\section{Antimicrobial activity}

The antimicrobial activity of the obtained essential oils was evaluated against a panel of six microorganisms using of agar disc diffusion method. The data expressed as diameter of growth inhibition zone $(\mathrm{mm})$. The results are illustrated in Table 5. All samples of volatile oils exhibited a high antibacterial 
and antifungal activity. The highest antibacterial activity was observed against gram positive bacteria Staphylococcus aureus, Bacillus cereus. Also Thymus serpyllum essential oils demonstrated a very high antifungal activity on Candida albicans. A high antimicrobial activity on gram-negative bacteria E. Coli and Klebsiella pneumonia was observed, while against other gramnegative bacteria Pseudomonas aeruginosa, the

Thymus serpyllum essential oils manifested a medium antibacterial activity. The standard used, amoxicillin, proved to be not effective on gramnegative bacteria Klebsiella pneumonia and Pseudomonas aeruginosa.

An improvment in antimicrobial activity of essential oil obtained using enzymatic assisted tratement was observed, which can be expalained by the composition percentages modification.

The antimicrobial activity of our Thymus serpyllum essential oils is in agreement with other literature results ${ }^{2,31}$. From literature the antimicrobial activity is assigned to the high concentration of carvacrol in essential oils ${ }^{32,33}$, but also to the presence of thymol in a high proportions ${ }^{34,35}$. Our study confirms the high antimiocrobial activity of essential oils containing large percentages of phenolic compounds.

The high antimicrobial activity of Thymus serpyllum essential oils from plants growing wild in Transylvania make them an important source of new therapeutic and antimicrobial preparates.

Table 5. Antimicrobial activity of studied essential oils

\begin{tabular}{|c|c|c|c|c|c|}
\hline \multirow{2}{*}{$\begin{array}{c}\text { Microbial } \\
\text { species }\end{array}$} & \multicolumn{5}{|c|}{ Inhibition diameter (mm) } \\
\cline { 2 - 6 } & Mociu & Tamasesti & Nasaud & $\begin{array}{c}\text { Nasaud } \\
\text { enzymatic }\end{array}$ & Amoxicillin \\
\cline { 2 - 5 } & $34 \pm 1$ & $35 \pm 1$ & $32 \pm 1$ & $35 \pm 1$ & $25 \pm 1$ \\
\hline $\begin{array}{c}\text { Staphylococcus } \\
\text { aureus }\end{array}$ & $24 \pm 1$ & $27 \pm 1$ & $25 \pm 1$ & $30 \pm 1$ & $12 \pm 1$ \\
\hline Bacillus cereus & $24 \pm 1$ & $30 \pm 1$ & $22 \pm 1$ & $25 \pm 1$ & $18 \pm 1$ \\
\hline E. coli & $16 \pm 1$ & $20 \pm 1$ & $14 \pm 1$ & $20 \pm 1$ & 0 \\
\hline $\begin{array}{c}\text { Klebsiella } \\
\text { pneumoniae }\end{array}$ & $7 \pm 1$ & $11 \pm 1$ & $7 \pm 1$ & $8 \pm 1$ & 0 \\
\hline $\begin{array}{c}\text { Pseudomonas } \\
\text { aeruginosa }\end{array}$ & $26 \pm 1$ & $30 \pm 1$ & $26 \pm 1$ & $30 \pm 1$ & $18 \pm 1$ \\
\hline $\begin{array}{c}\text { Candida } \\
\text { albicans }\end{array}$ & & & & \\
\hline
\end{tabular}




\section{CONCLUSIONS}

A comparative study for analysis of influence of the geographical location and also the influence of enzymatic assistant extraction on the essential oils isolated from Thymus serpyllum growing wild in Transylvania was achieved.

Analysing the composition of the essential oils of Thymus serppylum plants collected from different geographic areas of Transylvania showed that the plants are related, belonging to carvacrol chemotype class, but differences appear in composition and also the relative concentration of major compounds. The variation in the amount of carvacrol and other components might be connected with climatic and meteorologic conditions also with plant stage of development and metabolism.

The influence of enzymatic assistant extraction on the essential oils was studied. A highly variation in essential oil compounds proportion was observed which induced a remarkable effect on the antioxidant and antimicrobial activities. Enzyme assisted extraction could be consider as an alternative procedure to improve the quality of the essential oils and also some specific enzymes treatment might be used to modulate a specific activity. However, more studies and others hydrolytic enzymes should be investigate.

All studied essential oils demonstrated very high antioxidant and, antimicrobial activity, proving that essential oils isolated from plants growing wild in Transylvania, could be a good, inexpensive, natural, indigenous sources for natural food additives, new pharmaceutical preparates and also natural additives in cosmetic industry.

\section{EXPERIMENTAL SECTION}

\section{MATERIAL AND METHODS}

The Thymus serpyllum plants were collected from Nasaud area $\left(47^{\circ} 17^{\prime} 0^{\prime \prime} \mathrm{N} 24^{\circ} 24^{\prime} 24^{\prime \prime} \mathrm{E}\right)$ from Bistrita-Nasaud district, Tamasesti area $\left(7^{\circ} 30^{\prime} 12^{\prime \prime} \mathrm{N} 23^{\circ} 11^{\prime} 20^{\prime \prime} \mathrm{E}\right)$ from Maramures district, and Mociu area from Cluj district, all regions in Transylvania, Romania. The collected plants were identified at Faculty of Biology and Geology from 'Babes-Bolyai' University, Cluj-Napoca. The entire plants were naturally dried and grounded. All reactive and standards were purchased from Merck (Darmstadt, Germany). For the enzymatic treatment, a mixture of pectolytic and cellulotic enzymes, commercial preparate named Rapidase(DSM Food), was used. Antioxidant activity was determined using a Varian Cary 50 Spectrophotometer in a kinetic mode. 


\section{GC-MS Apparatus}

A Trace DSQ Thermo Finnigan quadrupole mass spectrometer coupled with a Trace GC was used. The Rtx-5MS capillary column, $30 \mathrm{mx} 0.25 \mathrm{~mm}$, $0.25 \mu \mathrm{m}$ film thickness was used in a temperature program from $50^{\circ} \mathrm{C}, 2 \mathrm{~min}$, then $8^{\circ} \mathrm{C} / \mathrm{min}$ to $250^{\circ} \mathrm{C}$, with $30^{\circ} \mathrm{C} / \mathrm{min}$ at $310^{\circ} \mathrm{C}(10 \mathrm{~min})$ for essential oils compounds analysis. Helium was used as carrier gas at a flow rate of $1 \mathrm{~mL} / \mathrm{min}$. $1 \mu \mathrm{L}$ of each sample was injected into the GC-MS using the split mode $(10: 1)$ using a TriPlus autosampler (Proanalysis, Bucharest, Romania). The mass spectrometer was operated in El mode at $70 \mathrm{eV}$, emission current was $100 \mu \mathrm{A}$ and mass spectra mass range 50-500 a.m.u. Transfer line temperature was set at $250^{\circ} \mathrm{C}$, injector at $250^{\circ} \mathrm{C}$ and ion source at $250^{\circ} \mathrm{C}$.

\section{Extraction Procedure for Essential Oils}

$50 \mathrm{~g}$ of dried plant were submitted to hydrodistilation in a Clevenger type apparatus for $4 \mathrm{~h}$. The collected essential oils were dried over anhydrous $\mathrm{Na}_{2} \mathrm{SO}_{4}$. For the GC-MS analysis samples were diluted $100 \mu \mathrm{L} / \mathrm{mL}$ in absolute ethanol.

\section{Enzymatic Assisted Treatment}

For enzymatic assisted treatment, $50 \mathrm{~g}$ of dried plant was treated with solution of $0.2 \%$ enzymatic preparate in water for $24 \mathrm{~h}$ at $37^{\circ} \mathrm{C}$. After the enzymatic treatment a Clevenger hydrodistilation was achieved to yield the essential oil.

\section{Determination of Antioxidant Activity}

For determination of antioxidant activity, DPPH antioxidant assay was used. Samples essential oils were used to decolorize an ethanolic solution of $40 \mu \mathrm{M} \mathrm{DPPH}$. The monitoring of DPPH reduction was followed at $517 \mathrm{~nm}$. The percentage of DPPH scavenging activity is expressed using following formula: $D P P H_{\text {inhibition }} \%=\left[\left(A_{i}-A_{t}\right) / A_{i}\right] \times 100$. For determination of effective concentration $\left(E_{50}\right)$, different concentration of essential oils $0.5,1$, $2,3,4,5 \mu \mathrm{L} / \mathrm{mL}$ in absolute ethanol were used. The $\mathrm{EC}_{50}$ was determined by

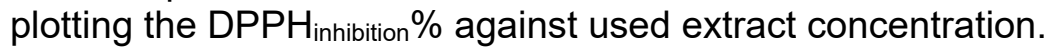

\section{Determination of Antimicrobial Activity}

In vitro antibacterial activity of the of the essential oils were tested using Agar Diffusion Test (ADT) with evaluation of inhibition zones (IZ). For testing the antibacterial activity of the obtained essential oils, two Gram-positive, three 
Gram-negative bacteria and a fungus were used as follow: Staphylococcus aureus ATCC 6538P, Bacillus cereus ATCC 14579, Escherichia coli ATCC 10536, Klebsiella pneumoniae (isolated from human urine), Pseudomonas aeruginosa ATCC 27853, Candida albicans. Amoxicillin $25 \mu \mathrm{g} / \mathrm{disc}$ was used as standard antibiotic in order to control the sensitivity of the microorganisms. The incubation conditions used were $24 \mathrm{~h}$ at $37^{\circ} \mathrm{C} .5 \mu \mathrm{l}$ of each volatile oils of Thymus serpyllum were applied on the paper disc, then disc papers were placed in the inoculated plates. After $24 \mathrm{~h}$ of incubation at 37 degrees Celsius the diameter of growth inhibition zones were measured.

\section{REFERENCES}

1. S. Jarik, M. Mitroviv, P. Pavlovic, Evidence-Based Complementary and Alternative Medicine, 2015, 1-10.

2. M. Nikolic, J. Glamoclija, I. Ferreira, R. Calhelha, Â. Fernandes, T. Markovic, D. Markovic, A. Giweli, M. Sokovic, Industrial Crops and Products, 2014, 52, 183190.

3. V. Vaiciulyte, R. Butkiene, K. Loziene, Phytochemistry, 2016, 1-7.

4. R.S. Verma, R.K. Verma, A. Chauhan, A.K. Yadav, Indian Journal of Pharmaceutical Sciences, 2011, 73 (1), 233-235.

5. A. Raal, U. Paaver, E. Arak, A. Orav, Medicina (Kaunas) 2004, 40(8), 795-800.

6. M.K Bhat. Biotechnology Advances, 2000, 18, 355-383.

7. I.S. Blank, D.H. Jaeger, B.D. Zurbriggen, US patent US6013289, 2000.

8. H.B Sowbhagya, K.T. Purnima, P. Suma Florence, A.G. Appu Rao, P. Srinivas, Food Chemistry, 113(4), 1234-1238, 2009.

9. H.B. Sowbhagya, P. Srinivas, Kaul T. Purnima, N. Krishnamurthy, Food Chemistry, 2011, 127, 1856-1861.

10. H.B. Sowbhagya, P. Srinivas, N. Krishnamurthy, Food Chemistry, 2010, 120, 230-234.

11. S. Dobozi, A. Halasz, K.E. Kovacs, G. Szacks, Applied Microbiology Biotechnology, 1988, 29(1), 39-43.

12. R.I. Santamaria, M.D. Duarte, E. Barzana, D. Fernando, F.M. Gama, M. Mota, Journal of Agricultural and Food Chemistry, 2000, 48(7), 3063-3067.

13. M. Salgado-Roman, E. Botello-Alvarez, R. Rico-Martinez, H. Jimenez-Islas, M. Cardenas-Manriquez, J.L. Navarrete-Bolanos, Journal of Agricultural and Food Chemistry, 2008, 56(21), 10012-10018.

14. K. Hosni, I. Hassen, H. Chaabane, M. Jemli, S. Dallali, H. Sebei, H. Casabianca, Industrial Crops and Products, 2013, 47, 291-299.

15. W.C Evans, "Trease and Evans Pharmacognosy", 15th Ed. Edinburgh Saunders, 2000. 
THE INFLUENCE OF GEOGRAPHIC LOCATION AND ENZYME-ASSISTED EXTRACTION ON ESSENTIAL OILS COMPOSITION OF THYMUS SERPYLLUM GROWING WILD IN TRANSYLVANIA

16. V. Kirillov, T. Stikhareva, B. Mukanov, N. Chebotko, O. Ryazantsev, G. Atazhanova, S. Adekenov, Journal of Essential Oil Bearing Plants, 2016, 19 (1), 212- 222.

17. A. Pruteanu, C. Popescu, V. Vladut, G. Gageanu, Romanian Biotechnological Letters, 2018, 23(5), 14013-14024.

18. U. Paaver, A. Orav, E. Arak, U. Maeorg, A. Raal, Natural Product Research, 2008, 22(2), 108-115.

19. B. Nikolić, M. Matović, K. Mladenović, M. Todosijević, J.Stanković, I. Dordević, P.D. Marin, V. Tešević, Natural Product Communications, 2019, 1-3.

20. E. Osinska, Z. Weglarz, M. Angielczyk, Proceeding XVIth EUCARPIA Genetic Resources, 2002, 253-256.

21. K Loziene, J Vaiciūniene, P R Venskutonis, Planta Medica, 1998, 64, 772-773.

22. Y.A. Banaeva, L.M. Pokrovsky, A.V. Tkachev, Proceedings of the International Conference on Natural Product and Physiologically Active Substance, 1998, 6-7.

23. M. Oszagyan, B. Simandi, J. Sawinsky, A. Kery, Journal of Essential Oil Research, 1996, 8, 333-335.

24. C. Da Porto, D. Decorti, Journal of Essential Oil Bearing Plants, 2012, 15, 561571.

25. A.I. Hussain, F. Anwar, S.A.S. Chatha, S. Latif, S.T.H. Sherazi, A. Ahmad, J. Worthington, S.D. Sarker, Food Science and Technology, 2013, 50, 185-192.

26. C. Rus, R.M. Sumalan, E. Alexa, D.M. Copolovici, G. Pop, D. Botau, Plant Soil and Environment, 2015, 61(7), 297-302.

27. T. Kulisic, A. Radonic M. Milos, Italian Journal of Food Science, 2005, 17(3), 315-324.

28. I. Rasooli, S.A. Mirmostafa, Fitoterapia, 2002, 73, 244-250.

29. G. Ilhami, Journal of Medicinal Food, 2011, 14, 975-985.

30. M. Hazzit, A. Baaliouamer, A.R. Veríssimo, M.L. Faleiro, M.G. Miguel, Food Chemistry, 2009, 116 (3), 714-721.

31. G. Kavita, K. Santosh, S. Reeta, Journal of Pharmacy Research, 2011, 4(3), 641-642.

32. N. Chorianopoulos, E. Kalpoutzakis, N. Aligiannis, S. Mitaku, G.J. Nychas, S. A. Haroutounian, Journal of Agricultural and Food Chemistry, 2004, 52(26), 8261-8267.

33. S. Bounatirou, S. Smiti, M.G. Miguel, Food Chemistry, 2007, 105(1), 146-155.

34. M. Sokovic, J. Glamocija, A. Ciric, Drug Development and Industrial Pharmacy, 2008, 34(12), 1388-1393.

35. M.D. Sokovic, J. Vukojevic, P.D. Marin, D.D. Brkic, V. Vajs, L.J.L.D. van Griensven, Molecule, 2009, 14(1), 238-249. 